\title{
The influence of slowly and rapidly degradable concentrate protein on nitrogen balance, rumen fermentation pattern and blood parameters in dairy cattle
}

\author{
W. A. G. Veen, J. Veling and Y. Tj. Bakker \\ CLO-Institute for Animal Nutrition 'De Schothorst', Meerkoetenweg 26, NL 8218 \\ NA Lelystad, Netherlands
}

Received 26 March 1987; accepted 30 November 1987

Key words: dairy cattle, concentrate protein, blood parameters, rumen, fatty acids, ketone bodies, insulin, amino acids, nitrogen digestibility

\begin{abstract}
In a cross-over trial, four fresh cows were given concentrates containing rapidly and slowly degradable protein in combination with prewilted grass silage. The animals were fed in two equal daily portions according to dcp and net energy requirements. The trial consisted of 3 main periods of three weeks each, with faeces, urine and milk collected and measured during the final week. On one day during this week samples of rumen fluid were taken and on two days blood samples were taken, directly before the morning feed and 1,2,3,4 and 8 hours later. $\mathrm{N}$ digestibility and $\mathrm{N}$ retention were the same on both rations. A concentrate with slowly degradable protein resulted in a significantly higher rumen $\mathrm{pH}$ and acetate/propionate ratio. Ammonia concentration tended to be lower. Slowly degradable concentrate protein led to a significantly higher concentration of urea and a lower concentration of insulin in the blood. The concentration of several of the essential amino acids and of the glucogenic amino acids and glycine was significantly lower. It was concluded that the ration containing slowly degradable concentrate protein resulted in a more gradual rumen fermentation, which promoted a higher acetate/propionate ratio in the rumen. On this ration apparently more gluconeogenesis from amino acids took place.
\end{abstract}

\section{Introduction}

In a series of seven feeding trials carried out between 1975 and 1985 , concentrates with slowly degradable protein were consistently found to have a positive effect on milk production and milk fat content, while the effect on protein content varied. Milk production was $0.6-1.8 \mathrm{~kg}$ higher, milk fat content was $0.09-0.28 \%$ higher and FCM production rose by $1.1-2.5 \mathrm{~kg}$ per animal per day. Rations containing slowly 
degradable concentrate protein resulted in a lower concentration of total volatile fatty acids and a higher acetate/propionate ratio in rumen fluid during the first 3 hours after concentrate feeding, which may explain the higher milk fat content.

However, rumen parameters did not account for all the results obtained during the trials. The higher concentration of urea in the blood of cows on a ration with slowly degradable protein, combined with the lower concentration of glucogenic amino acids, led to the conclusion that on this type of ration more gluconeogenesis from amino acids took place. The positive correlation between urea concentration in the blood and milk production indicates that increased gluconeogenesis from amino acids leads to higher milk production (Veen \& Bakker, 1988). A lower insulin level in the blood can be seen as a favourable factor, because it results in a relatively higher degree of utilization of glucose by the udder. Insulin production has been found to be determined to a large extent by the production of volatile fatty acids in the rumen (Johnson et al., 1982; Bines \& Hart, 1984).

On the basis of these findings we decided to measure both rumen and blood parameters in a single trial. As the concentration of most metabolites in the rumen and the blood gradually alters during the hours following feeding, several samplings were carried out during the daytime feeding cycle of cows fed twice daily. In addition, we determined whether the rations with rapidly and slowly degradable protein differed in their effect on the digestibility of the feed nitrogen and the ratio in which absorbed $\mathrm{N}$ was distributed between milk and body tissue.

\section{Material and methods}

\section{Design}

The trial consisted of 3 main periods of 3 weeks each; the first two weeks were for adaptation, while during the third week the observations were recorded. The main periods were separated by a two-week period during which all cows received the same commercial concentrate.

The trial involved 4 crossbreeds of Holstein Friesians and Dutch Friesians. All the cows calved within a period of 9 days. From on average the fifth week of lactation they were kept tethered in a tie-stall barn. With the cows a $\mathrm{N}$ balance trial was carried out. The facilities were such that it was possible to collect the faeces and

Table 1. Experimental design: allocation of cows to treatment.

\begin{tabular}{lll}
\hline Period & Treatment & \\
& b & B \\
1 & Jetske 625, His 485 & Jetske 627, His 467 \\
2 & Jetske 627 & Jetske 625, His 485 \\
3 & Jetske 625, His 485 & Jetske 627 \\
\hline
\end{tabular}

${ }^{1} \mathrm{~b}=$ rapidly degradable protein; $\mathrm{B}=$ slowly degradable protein. 
urine separately in plastic crates. The urine was collected by means of a bladder cathether and blood samples were taken from the vena jugularis. Cows were fitted with a rumen fistula. The cows were weighed at the beginning and end of each main period. Table 1 shows the distribution of the cows over the various treatments and periods. In the third main period one cow (His 467) was removed from the trial due to a serious kidney defect. Results of the analysis of the blood samples of the second period indicated that the renal function of this cow was even then impaired, so that these results were not included in subsequent calculations.

Two concentrates with respectively rapidly (b) and slowly degradable protein (B) were compared; the roughage/concentrate ratio was maintained at $40 / 60$ as a proportion of dry matter. For each kind of concentrate two formulas were available, one with a low and one with a high protein content. The composition is given in Table 2. In order to meet the requirements for protein and net energy, mixtures

Table 2. Composition of the concentrates $(\%)$.

\begin{tabular}{|c|c|c|c|c|}
\hline & $b_{L}^{1}$ & $\mathrm{bH}$ & BL & $\mathrm{BH}$ \\
\hline Breweries grains, dried & - & - & 7.00 & 21.80 \\
\hline Citrus pulp, dried & 33.50 & 15.60 & 25.00 & 12.40 \\
\hline Groundnut expeller & - & 10.00 & - & - \\
\hline Rape seed meal, solv. extr. & 1.20 & 15.00 & - & - \\
\hline Lupin & 6.80 & 15.00 & - & - \\
\hline Maize gluten meal & - & - & - & 15.60 \\
\hline Hominy feed & - & - & 23.50 & - \\
\hline Molasses, cane & 6.00 & 6.00 & 6.00 & 6.00 \\
\hline Maize gluten feed & 35.00 & 25.00 & - & - \\
\hline Beet pulp, dried & 10.00 & 4.60 & 15.00 & 25.00 \\
\hline Palm kernel expeller & - & - & 10.00 & 5.00 \\
\hline Soya bean meal, solv. extr. & - & 6.70 & 6.40 & 12.00 \\
\hline Tapioca meal & 5.70 & - & 5.00 & - \\
\hline $\mathrm{CaHPO}_{4}$ & 0.50 & - & 0.80 & 0.60 \\
\hline Limestone & - & 0.80 & - & 0.30 \\
\hline Salt & 0.80 & 0.80 & 0.80 & 0.80 \\
\hline Vitamins/minerals concentrate & 0.50 & 0.50 & 0.50 & 0.50 \\
\hline \multicolumn{5}{|l|}{ Chemical composition } \\
\hline Dry matter (g/kg) & 888 & 889 & 891 & 896 \\
\hline Crude protein $(\mathrm{g} / \mathrm{kg})$ & 130 & 235 & 132 & 244 \\
\hline \multicolumn{5}{|l|}{ Digestible crude protein } \\
\hline (calculated) $(\mathrm{g} / \mathrm{kg})$ & 90 & 200 & 90 & 200 \\
\hline VEM (calculated $)^{2}$ & 945 & 944 & 940 & 941 \\
\hline Nitrogen solubility ${ }^{3}(\%)$ & 40 & 40 & 24 & 13 \\
\hline Protein degradability ${ }^{4}(\%)$ & 75 & 75 & 60 & 32 \\
\hline
\end{tabular}

${ }^{\prime} \mathrm{b}=$ rapidly degradable protein; $\mathrm{B}=$ slowly degradable protein $\mathrm{L}=$ low protein; $\mathbf{H}=$ high protein.

2 Dutch feed unit of energy (van Es, 1978).

${ }^{3}$ In mineral buffer, according to Crooker et al. (1978).

4 In sacco after $12 \mathrm{~h}$. 
of high- and low-protein concentrates with about the same protein degradability were made. All feeds contained equal net-energy milk. The quantity of feed administered per day during a main 3-week period was determined on the basis of production during the previous interim period. In the interim periods the animals were fed according to digestible crude protein requirement on the basis of production during the previous three weeks. Concentrates and roughage, which were fed simultaneously but in separate containers, were administered in two equal daily portions at $8: 00$ and $17: 00 \mathrm{~h}$. The roughage consisted of grass silage; a sufficient supply of it was stored at $-20^{\circ} \mathrm{C}$ for the duration of the whole trial. Silage contained $588 \mathrm{~g}$ dry matter per $\mathrm{kg}$ and $203 \mathrm{~g}$ crude protein per kg dry matter. Protein degradability of concentrates was determined as previously described (Veen \& Bakker, 1988). Six cows were used for this purpose. They were offered a commercial concentrate and prewilted grass silage (60/40 as a proportion of dry matter) in two equal daily portions.

\section{Sampling}

During the observation periods, faeces and urine were quantitatively collected in plastic receptacles from 8:30 h Monday morning up to, and including, 8:30 h Saturday morning. With the aid of a $3.5 \mathrm{M}$ solution of sulphuric acid, the acid level of the urine was kept sufficiently high to prevent ammonia losses. Each day at 14:00 h, faeces and urine were carefully weighed and homogenized, and a percentage sample was taken. Cows were milked at 7:00 and at 16:00 h. During the whole trial period, milk was weighed and samples were taken at every milking from Monday evening through Wednesday morning. Samples were pooled and analysed for fat and protein content. These data were used for establishing feed requirements. During the observation periods milk was collected at each milking from Monday morning to Saturday morning. After homogenizing and weighing a percentages sample was taken.

The faeces, urine and milk samples collected were protected against bacterial fermentation during storage by using formaldehyde solution, sulphuric acid and $\mathrm{HgCl}_{2}$ solution, respectively. At the end of the collection period, samples were thoroughly homogenized and sub-sampled again, for purposes of further analysis. In the faeces, dry matter and $\mathrm{N}$ were determined; in the urine, $\mathrm{N}$; and in the milk, protein and fat. At 7:30 h each morning during the observation periods, feed refusals were collected, bulked on a weekly basis, homogenized and ground; dry matter and $\mathrm{N}$ were determined.

In the week that the balance trial was carried out, rumen fluid was sampled on Tuesday morning and the blood from the vena jugularis on Tuesday and Wednesday morning. The first sample of rumen fluid was taken immediately before the morning feeding and the following samples 1,2,3 and 4 hours later. An additional sample was taken directly before the evening feed (approximately 8 hours after the first sample). Immediately after each sampling of rumen fluid, a blood sample was taken. In the rumen fluid the $\mathrm{pH}$ was immediately determined. Samples were frozen and stored for later determination of the concentration of ammonia and volatile fatty acids. In the blood, concentration of urea, glucose, ketone bodies, insulin, 
acetate, non-esterified fatty acids (NEFA) and amino acids was determined.

\section{Chemical determinations}

Analysis of rumen fluid has already been described (Veen, 1986), as well as the majority of analyses in blood (Veen \& Bakker, 1988). In blood plasma, glucose was determined with the test combination GOD Perid, a product of Boehringer Mannheim GmbH Diagnostica. Acetate was determined in blood plasma in the same manner as in rumen fluid. For the fatty acid analysis, milk fat was extracted according to Walstra \& Mulder (1982). Methyl esters of fatty acids were separated by capillary gas chromatography.

\section{Calculations}

All data were analysed by an analysis of variance according to the model:

$$
Y_{i j k}=P_{i}+C_{j}+T_{k}+E_{i j k}+\mu
$$

where $P=$ period, $C=$ cow, $T=$ treatment, $E=$ rest variation and $\mu=$ mean (Snedecor \& Cochran, 1967). Metabolite concentrations in plasma were averaged over the two consecutive sampling days before statistical analysis. Concentrations of aspartic acid and proline were generally very low, while the level of arginine displayed a flat peak. As it was not possible to accurately quantify these peaks, they were not included in the calculations. For rumen and blood parameters the effect of treatments was calculated for the averages of all sampling times. For $t=0$ to $t=4 \mathrm{~h}$ the curves of the concentration course with the time were evaluated for linear and quadratic effects by orthogonal polynomials. Least square means were used for plotting curves. The calculation of the energy value of the milk produced was based on the following values: milk fat $38.5 \mathrm{~kJ} / \mathrm{g}$, milk protein $24.52 \mathrm{~kJ} / \mathrm{g}$ and lactose 16.53 $\mathrm{kJ} / \mathrm{g}$.

\section{Results}

The protein degradability of concentrate BL proved higher than had been expected. However, the mixture of BL and BH that was used for the required dcp supply had an average degradability of $56.6 \pm 0.3$. A feeding trial involving 96 cows was carried out using the same concentrates as in the balance trial. On treatment $B$, average daily milk production was $1.1 \mathrm{~kg}$ higher (n.s.) than on treatment b, while milk fat content and milk protein content were $0.26 \%$ and $0.09 \%$ higher $(P<$ 0.01 ), respectively (Veling, Veen \& Bakker, intern. rep.).

\section{Milk production and $N$-balance}

Data on milk production and $\mathrm{N}$-balance are summarized in Table 3 , which also 
Table 3. Effect of treatment on milk production and nitrogen balance.

\begin{tabular}{lcclc}
\hline & $b$ & B & $\begin{array}{l}\text { Significance of } \\
\text { difference }\end{array}$ & SEE $^{2}$ \\
Milk (kg/day) & 26.43 & 26.73 & n.s. & 0.83 \\
Fat (g/day) & 1090 & 1159 & n.s. & 53 \\
Fat content (\%) & 4.11 & 4.31 & n.s. & 0.14 \\
N-intake (g/day) & 488 & 489 & n.s. & 9 \\
N digested (g/day) & 307 & 308 & n.s. & 9 \\
N excreted in urine (g/day) & 163 & 164 & n.s. & 4 \\
N excreted in milk (g/day) & 123 & 125 & n.s. & 4 \\
N retained in body (g/day) & 20 & 18 & n.s. & 14 \\
& & & & \\
Digestibility dry matter (\%) & 71.9 & 72.0 & n.s. & 0.67 \\
Digestibility N (\%) & 62.9 & 63.0 & n.s. & 0.01 \\
Urine N/digested N (\%) & 53.5 & 53.7 & n.s. & 0.03 \\
Milk N/digested N (\%) & 39.9 & 40.7 & n.s. & 0.02 \\
Retained N/digested N (\%) & 6.7 & 5.4 & n.s. & 0.05 \\
& & & & 0.03 \\
NEL intake/NEL output in milk & 1.05 & 1.01 & n.s. & \\
\hline
\end{tabular}

n.s. = not significant.

${ }^{2}$ SEE $=$ standard error estimate.

shows the ratio of intake of net energy for lactation and the energetic value of the milk produced. Because there were only three degrees of freedom, significant differences could hardly be expected. Nevertheless the milk production data showed the same tendency as found in the preceding feeding trials mentioned above. No differences in digestibility of dry matter and nitrogen were found. Partition of nitrogen between milk and tissue protein also did not differ significantly. There was a tendency towards a higher ratio of NEL intake/energy output in milk with intake of rapidly degradable protein. In calculating net energy requirement for milk production, energy requirement for maintenance was included (van Es, 1978). So the theoretical net energy ratio had to be 1.00 , which was almost found with treatment B.

During the whole trial period the three cows which completed the trial lost between 28 and $36 \mathrm{~kg}$ in body weight.

\section{Rumen fluid}

The $\mathrm{pH}$ course and the concentration of ammonia and volatile fatty acids from $t=0$ to $t=4 \mathrm{~h}$ is given in Figs. 1 and 2. Table 4 shows the average values for the period from $t=0$ to $t=8 \mathrm{~h}$. On the treatment with rapidly degradable concentrate protein the $\mathrm{pH}$ was lower at all sampling times after the morning feeding. The $\mathrm{pH}$ declined after feeding and the lowest value was recorded 2 hours later. Directly before afternoon feeding $(t=8 \mathrm{~h})$ the $\mathrm{pH}$ had still not regained the initial value. On average, $\mathrm{pH}$ was significantly lower on treatment $\mathrm{b}$ (Table 4). During the first hour following 


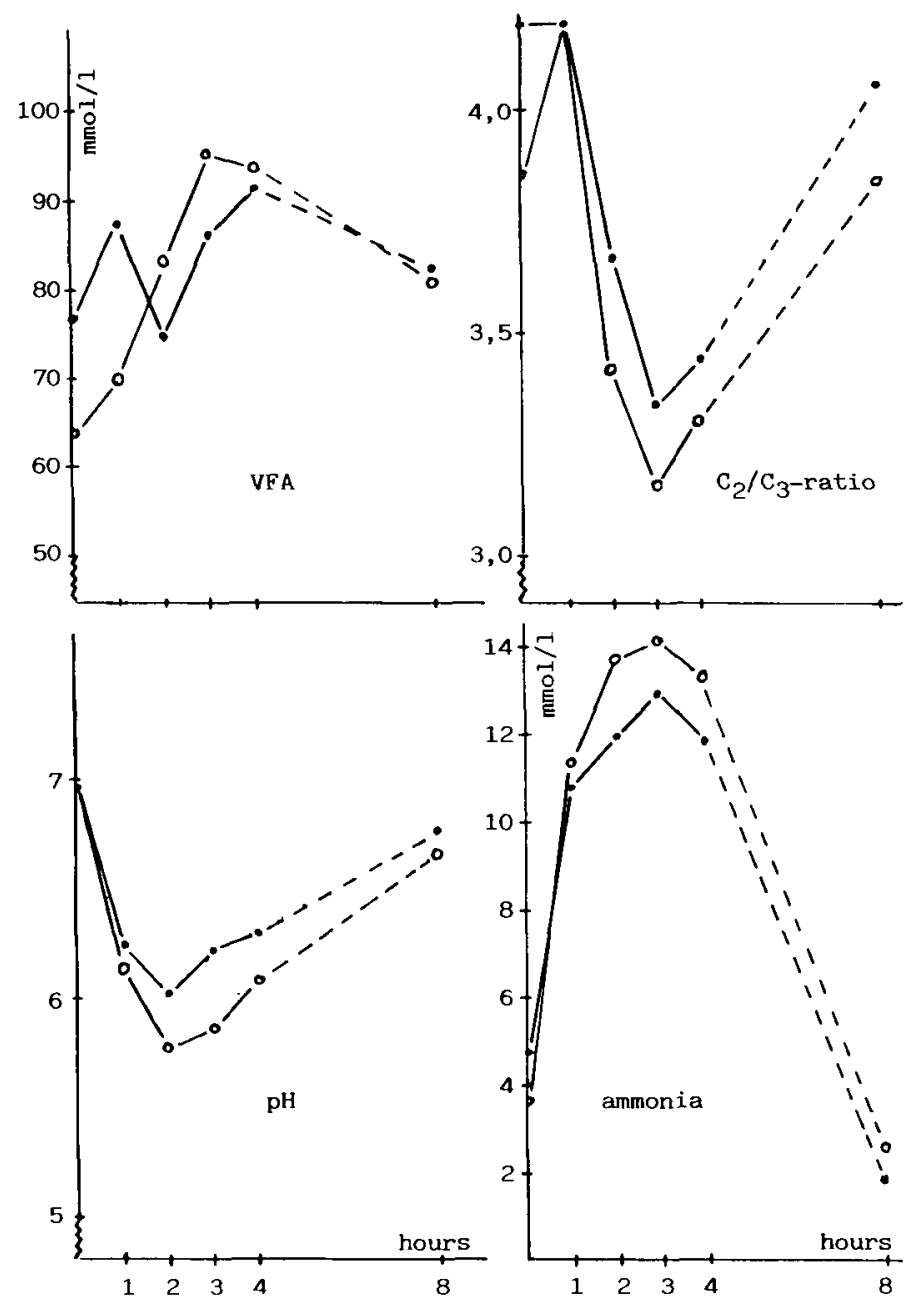

Fig. 1. pH, ammonia concentration, VFA concentration and acetate/propionate ratio in rumen fluid during time after morning feeding. $\mathrm{O}-\mathrm{O}$ rapidly degradable concentrate protein (b); -0 slowly degradable concentrate protein $(B)$.

feeding the concentration of ammonia rose more sharply on treatment $b$ than on treatment $B$. On both rations the highest concentration was reached after 3 hours. On treatment B the concentration at $t=8 \mathrm{~h}$ was significantly lower than at $t=0 \mathrm{~h}$ $(P<0.01)$.

The concentration of the main volatile fatty acids invariably increased after feeding. However, on treatment $\mathrm{B}$ the concentration of acetic acid dropped between $t=$ 

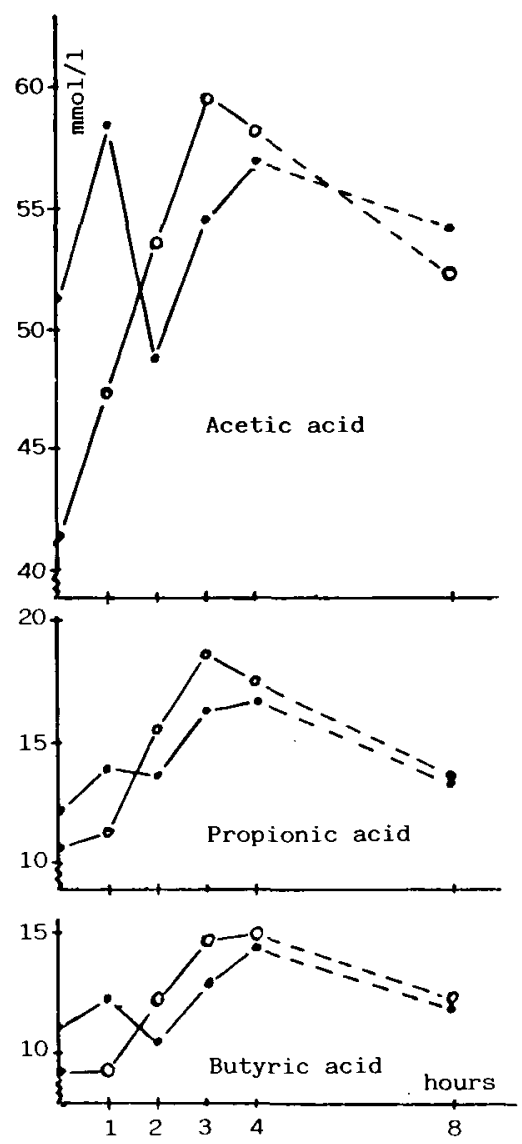

Fig. 2. Concentration of acetic, propionic and butyric acid in rumen fluid during time after morning feeding. $\bigcirc-O$ rapidly degradable concentrate protein (b); - slowly degradable concentrate protein (B).

1 and $t=2 \mathrm{~h}$. Mean values for the main VFA did not differ (Table 4). Fig. 2 shows that at 2,3 and $4 \mathrm{~h}$ and, with the exception of acetic acid, at $t=8 \mathrm{~h}$ as well, concentrations of the main fatty acids were higher on treatment $b$. However, per time unit, these differences were not significant. It is nevertheless clear that on treatment $b$ the concentrations increased more rapidly after feeding than on treatment $\mathrm{B}$. The acetate/propionate ratio was at all times higher on treatment $B$. On average the difference was significant (Table 4). Significant differences between the two treatments were also noted for iso-butyric acid and 2-methylbutyric acid. Concentration of all the branched fatty acids was at most times higher on treatment B. From $t=2 \mathrm{~h}$ on, concentration of valeric acid was lower on treatment B (not shown in figures). 
Table 4. Effect of treatment on average $\mathrm{pH}$, acetate/propionate ratio and concentration of ammonia and volatile fatty acids in rumen fluid from $t=0$ to $t=8 \mathrm{~h}$.

\begin{tabular}{lrrlr}
\hline & \multicolumn{1}{c}{ b } & B & $\begin{array}{l}\text { Significance of } \\
\text { difference }\end{array}$ & SEE $^{2}$ \\
pH & 6.28 & 6.43 & $*$ & 0.21 \\
Ammonia $(\mathrm{mmol} / \mathrm{l})$ & 9.81 & 9.01 & n.s. & 1.51 \\
Acetic acid $(\mathrm{mmol} / \mathrm{l})$ & 52.18 & 53.66 & n.s. & 8.68 \\
Propionic acid $(\mathrm{mmol} / \mathrm{l})$ & 14.68 & 14.33 & n.s. & 2.78 \\
Butyric acid $(\mathrm{mmol} / \mathrm{l})$ & 12.15 & 12.13 & n.s. & 2.57 \\
Valeric acid $(\mathrm{mmol} / \mathrm{l})$ & 1.51 & 1.27 & n.s. & 0.39 \\
Iso-butyric acid $(\mathrm{mmol} / \mathrm{l})$ & 0.45 & 0.54 & $*$ & 0.12 \\
2-methylbutyric acid $(\mathrm{mmol} / \mathrm{l})$ & 0.32 & 0.48 & $* *$ & 0.12 \\
Iso-valeric acid $(\mathrm{mmol} / \mathrm{l})$ & 0.36 & 0.44 & n.s. & 0.15 \\
Total VFA (mmol/l) & 81.64 & 82.86 & n.s. & 14.35 \\
Acetate/propionate & 3.63 & 3.81 & $*$ & 0.25 \\
\hline
\end{tabular}

$1{ }^{*} P<0.05,{ }^{* *} P<0.01$, n.s. $=$ not significant.

$2 \mathrm{SEE}=$ standard error estimate.

\section{Blood}

Table 5 shows the average concentration of various blood metabolites and insulin between $t=0$ and $t=8 \mathrm{~h}$. Fig. 3 shows the course from $t=0$ to $t=4 \mathrm{~h}$. None of the concentrations measured showed any interaction between treatment and time. The difference in the average concentration of insulin was statistically significant. The concentration of urea was at all times significantly lower on treatment $b$ than on treatment $\mathrm{B}$. The concentration of urea increased linearly with time. The concentration of NEFA was characterized by marked individual variations, so that no significant difference was recorded for any point in time. After feeding, the concentra-

Table 5. Effect of treatment on average concentration of urea, glucose, NEFA, ketone bodies, acetate and insulin in blood from $t=0$ to $t=8 \mathrm{~h}$.

\begin{tabular}{lcclc}
\hline & $\mathrm{b}$ & $\mathrm{B}$ & $\begin{array}{l}\text { Significance of } \\
\text { difference }\end{array}$ & SEE $^{2}$ \\
Urea, plasma $(\mathrm{mmol} / \mathrm{l})$ & 4.73 & 5.38 & $* *$ & 0.24 \\
Glucose, plasma $(\mathrm{mmol} / \mathrm{l})$ & 3.54 & 3.50 & n.s. & 0.12 \\
NEFA, plasma $(\mu \mathrm{mol} / \mathrm{l})$ & 357 & 343 & n.s. & 117 \\
Ketone bodies, blood $(\mathrm{mmol} / \mathrm{l})$ & 0.72 & 0.68 & n.s. & 0.95 \\
Acetate, plasma $(\mathrm{mmol} / \mathrm{l})$ & 0.74 & 0.74 & n.s. & 0.26 \\
Insulin, plasma $(\mathrm{mU} / \mathrm{l})$ & 27.13 & 22.92 & $*$ & 6.47 \\
\hline
\end{tabular}

${ }^{*} P<0.05,{ }^{* *} P<0.01, \mathrm{n} . \mathrm{s} .=$ not significant.

2 SEE $=$ standard error estimate. 


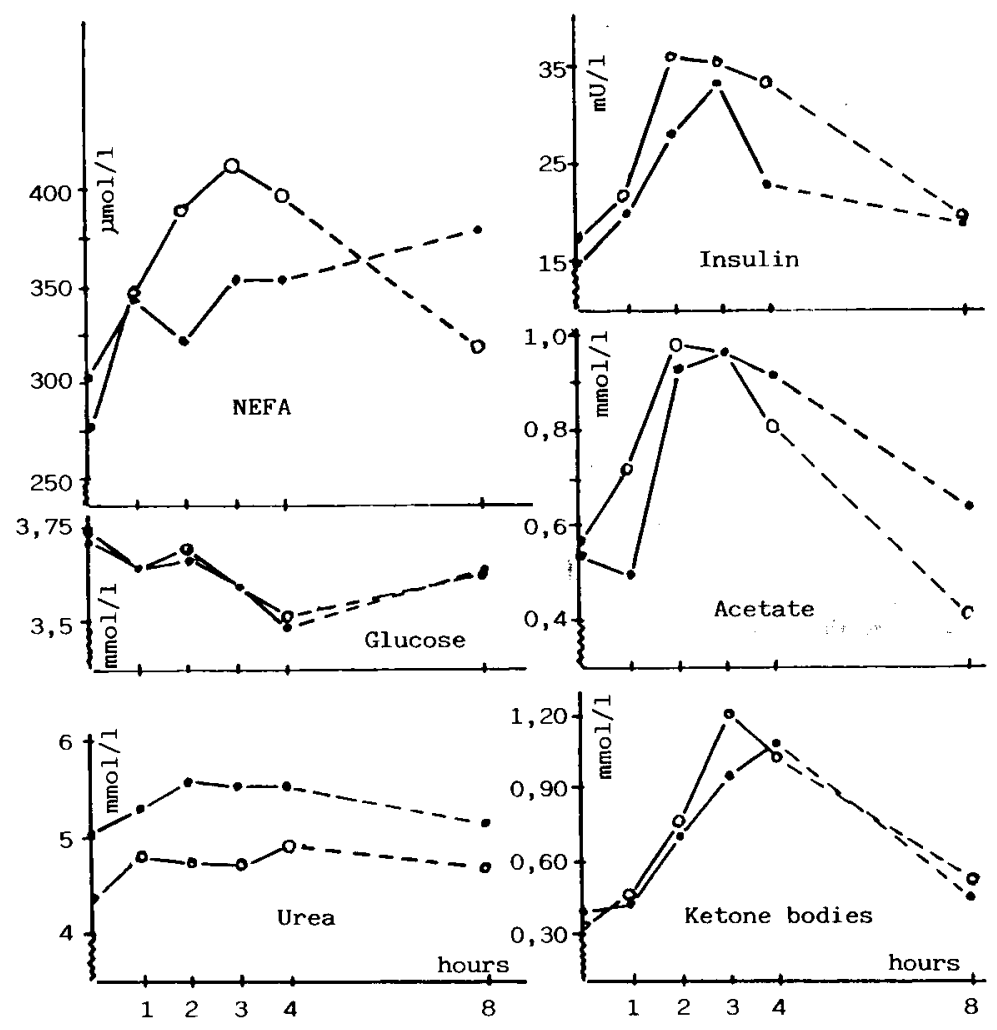

Fig. 3. Concentration of blood components during time after morning feeding (concentrations in plasma, except for ketone bodies which was in whole blood). $\mathrm{O}-\mathrm{O}$ rapidly degradable concentrate protein (b); slowly degradable concentrate protein (B).

tion of NEFA increased more rapidly on treatment $b$ than on treatment $B$. From three hours after feeding, the concentration decreased on treatment $b$, while on treatment B it continued to increase. On treatment B the concentration of ketone bodies was significantly lower only at $t=3 \mathrm{~h}$, but not on average. The concentration increased linearly. The concentration of glucose decreased linearly and that of acetate increased. On average, differences were not significant between treatments. The concentration of amino acids is given in Table 6 . The classification of the amino acids is the same as that used by Rémond et al. (1971), who considered only aspartic acid, glutamic acid, serine, proline, alanine and glycerine as non-essential amino acids, and the remaining acids as essential or semi-essential. Where a significant linear time course was observed, this involved a decrease in the concentration. The decline was most pronounced in the case of glycine. Of the essential amino acids the 
Table 6. Effect of treatment on average concentration of amino acids in plasma from $t=0$ to $t=8 \mathrm{~h}$ $(\mu \mathrm{mol} / \mathrm{l})$.

\begin{tabular}{lrrrr}
\hline & b & B & $\begin{array}{l}\text { Significance of } \\
\text { difference }\end{array}$ & SEE $^{2}$ \\
Essential amino acids & & & & \\
Threonine & & & & \\
Valine & 404 & 323 & $* *$ & 68 \\
Methionine & 337 & 291 & $* *$ & 18 \\
Isoleucine & 46 & 53 & n.s. & 14 \\
Leucine & 132 & 125 & n.s. & 15 \\
Tyrosine & 173 & 166 & n.s. & 18 \\
Phenylalanine & 65 & 78 & $*$ & 62 \\
Histidine & 46 & 54 & n.s. & 100 \\
Tryptophan & 234 & 184 & $*$ & 27 \\
Lysine & 161 & 248 & $* *$ & 33 \\
Non-essential amino acids & 119 & 99 & $*$ & 13 \\
Serine & & & & 68 \\
Glutamic acid & & & & \\
Glycine & 179 & 155 & $*$ & $* *$ \\
Alanine & 72 & 55 & $* *$ & \\
\hline
\end{tabular}

${ }^{*} P<0.05,{ }^{* *} P<0.01$, n.s. $=$ not significant.

${ }^{2} \mathrm{SEE}=$ standard error estimate.

concentration of methionine, isoleucine and phenylalanine was not different between treatments. The concentration of threonine, valine, histidine and lysine was significantly lower on treatment $\mathrm{B}$, and that of tyrosine and tryptophan significantly higher. The concentration of non-essential amino acids was significantly lower on treatment B.

\section{Milk fatty acid pattern}

In determining the milk fatty acid pattern, only the fatty acids with an even number of $\mathrm{C}$ atoms were taken into account. The remaining fatty acids make up approximately $10 \%$ of the total number (Muuse et al., 1986). Table 7 shows the molar ratio of the most important fatty acids. For the statistical analysis there were only three degrees of freedom. Nevertheless there were several significant differences. On treatment $B$ the share of lauric acid $\left(\mathrm{C}_{12: 0}\right)$, and myristic acid $\left(\mathrm{C}_{14: 0}\right)$ was higher, while that of the fatty acids with $18 \mathrm{C}$ atoms was lower. Assuming that $85 \%$ of the milk fat consisted of the even-numbered fatty acids $(10 \%$ remaining fatty acids and $5 \%$ glycerol), we calculated the average daily excretion of fatty acids with the milk. The results are given in Table 8 . Secretion of the fatty acids with 12 to 16 carbon atoms was higher on treatment $\mathrm{B}$ and that of C18-fatty acids was lower. 
Table 7. Effect of treatment on milk fatty acid pattern (molar percentages).

\begin{tabular}{rrrll}
\hline Fatty acid $^{\prime}$ & b & B & $\begin{array}{l}\text { Significance of } \\
\text { difference }\end{array}$ & SEE $^{3}$ \\
$4: 0$ & & & & \\
$6: 0$ & 9.08 & 9.59 & n.s. & 0.45 \\
$8: 0$ & 4.98 & 5.10 & n.s. & 0.18 \\
$10: 0$ & 2.47 & 2.51 & n.s. & 0.16 \\
$12: 0$ & 5.30 & 5.42 & n.s. & 0.24 \\
$14: 0$ & 4.95 & 6.14 & $* *$ & 0.10 \\
$16: 0$ & 12.48 & 13.80 & $* *$ & 0.25 \\
$16: 1$ & 30.34 & 31.53 & n.s. & 0.38 \\
$18: 0$ & 1.27 & 1.29 & n.s. & 0.05 \\
$18: 1$ & 9.26 & 8.26 & n.s. & 0.55 \\
$18: 2$ & 16.66 & 13.82 & $*$ & 0.81 \\
18.16 & 2.49 & n.s. & 0.28 \\
\hline
\end{tabular}

${ }^{1}$ Short-hand designation: number of carbon atoms and double bonds.

$2{ }^{*} P<0.05,{ }^{* *} P<0.01$, n.s. $=$ not significant.

${ }^{3} \mathrm{SEE}=$ standard error estimate.

Table 8 . Effect of treatment on mean daily secretion of fatty acids in milk fat ( $\mathrm{g} / \mathrm{day}$ ).

\begin{tabular}{|c|c|c|c|c|}
\hline Fatty acid ${ }^{1}$ & b & B & $\begin{array}{l}\text { Significance of } \\
\text { difference }^{2}\end{array}$ & $\mathrm{SEE}^{3}$ \\
\hline $4: 0$ & 32.2 & 36.6 & n.s. & 2.8 \\
\hline $6: 0-10: 0$ & 74.9 & 82.4 & n.s. & 3.4 \\
\hline $12: 0-16: 1$ & 486.1 & 563.0 & * & 31.3 \\
\hline $18: 0-18: 2$ & 333.5 & 303.1 & * & 11.7 \\
\hline
\end{tabular}

Short-hand designation: number of carbon atoms and double bonds.

${ }^{2} P<0.05,{ }^{* *} P<0.01$, n.s. $=$ not significant.

${ }^{3} \mathrm{SEE}=$ standard error estimate.

\section{Discussion}

\section{Milk production and $N$ balance}

Data on milk production and milk fat content suggest that the results of this experiment were representative for what can be expected when comparing concentrates with slowly and rapidly degradable protein. Although no statistical differences were found the results suggest that it would be worth to examine further if rations with slowly degradable concentrate protein promote preferential use of amino acids for milk production.

The tendency of a higher NEL intake than actually secreted with the milk is in accordance with results of two feeding trials where we found a $5 \%$ and $12 \%$ higher ratio NEL intake/energy output on a ration with rapidly degradable protein as compared to slowly degradable protein. These differences were significant (Bakker, 
Veen \& Cornelissen, 1984, intern. rep.; Veling, Veen \& Bakker, 1986, intern. rep.). In the second of these trials the same concentrates were used as in the balance trial described here.

In these feeding trials there was no significant difference in weight gain during the entire trial, while in the case of the balance trial neither of the two treatments resulted in a significant alteration in weight during the periods the $\mathrm{N}$ balance was measured. One explanation for the difference in the percentage supply of net energy requirement could be that one or both of the feeds deviated from the calculated NEL value. This is not likely, however, as the feeds were chemically analysed and the values from the CVB (Central Bureau for Livestock Feeding in the Netherlands)-table were only used for the digestibility coefficients. There was no difference between the two feeds in digestion of dry matter. It is more likely that on treatment $b$ more energy was used for deposition of body tissue and that this fact was not reflected in statistically significant differences in weight. In this regard it is important to note that treatment $b$ led to a significantly higher concentration of insulin in the blood. Insulin promotes the uptake of certain amino acids in muscle tissue (Brockman \& Laarveld, 1986).

\section{Rumen fermentation}

Patterns of rumen fermentation were comparable to results of several previous trials (Veen, 1986). It was only on treatment $\mathrm{b}$ that the $\mathrm{pH}$ level temporarily fell below 6. On both treatments the peak in ammonia concentration occured after 3 hours, which is later than when concentrates only are fed (Veen, 1986). The difference in concentration between treatments was also less pronounced; this has to do with the production of ammonia from rapidly fermentable $\mathbf{N}$ sources in the grass silage, as previously discussed (Veen, 1986). The higher acetate/propionate ratio on a ration with slowly degradable protein was also found in several previous trials (Veen, 1986). Blauwiekel \& Kincaid (1986) also recorded a significantly higher acetate/ propionate ratio for a ration with little soluble $\mathrm{N}$ as compared to one with a great deal of soluble N. Sutton et al. (1986) found that there was a tendency towards a higher ratio of acetate and butyrate/propionate when cows were fed more frequently than twice a day. Our findings and those of Blauwiekel \& Kincaid (1986) point to a more gradual fermentation when a concentrate with slowly degradable protein is fed. This result can also be obtained by more frequent feeding. The effect is probably due to decreased displacement of cellulolytic bacteria by amylolytic bacteria, as previously discussed (Veen, 1986).

\section{Blood parameters}

The concentration values of NEFA displayed an extremely wide range of variation. This may well be due to the different reactions to the stress of blood sampling; excitement can cause a rapid rise in the concentration of NEFA (Bowden, 1971). There was a tendency towards a lower concentration of NEFA on treatment B at a number of times after feeding. In previous trials a lower concentration was re- 
corded for treatment B immediately before the morning feed (Veen \& Bakker, 1988). Blauwiekel \& Kincaid (1986) found that the in vitro solubility of the concentrate protein had no effect on the NEFA concentration in the blood of cows. Our data provide an indication that feeding slowly fermentable protein slightly reduces the mobilization of adipose fat. This points to a relatively better energy supply, probably by a higher glucose production from amino acids. However, the importance of the concentration of NEFA in the plasma as a parameter for the energy status of ruminants is unresolved (Bowden, 1971; Roberts et al., 1978; Bartle et al., 1983).

The increase in the concentration of ketone bodies after feeding probably reflects the production of butyric acid in the rumen. The significantly higher concentration registered on treatment $b 3$ hours after feeding paralelled the higher concentration of butyric acid in the rumen (Fig. 2).

The concentration of insulin increased during the first two to three hours after feeding and was on a lower level when slowly degradable protein was fed. In cattle and sheep, propionic acid in the blood stimulates release of insulin more than glucose (Johnson et al., 1982; Bines \& Hart, 1984; Johnson et al., 1986). The concentration of propionic acid in rumen fluid was lower at 2-4 hours after feeding, although not significantly. Insulin plays no important active role in the uptake of glucose by the udder (Laarveld, 1981). A higher concentration of insulin may lead to uptake of glucose by muscle and fat tissue. In high-yielding cows which have a lower insulin level than low-yielding cows (Hart et al, 1978), glucose is apparently preferentially used for milk synthesis. Glucose is the most important precursor of lactose (Bickerstaffe et al., 1974). The concentration of glucose gradually declined after feeding in accordance with results of Bines (1968). Evans et al. (1975) found that after feeding the glucose concentration gradually increased. There was no difference in glucose concentration in peripheral blood due to the experimental treatment. However this does not rule out the possibility that there was a difference in glucose supply to the udder.

As in previous trials (Veen \& Bakker, 1988), a higher urea concentration was registered on the treatment with slowly degradable protein. Whitelaw et al. (1986), recorded a higher urea concentration in the plasma of cows when $600 \mathrm{~g}$ casein was administered via an abomasal infusion. Both an abomasal infusion and a feed with slowly degradable protein led to an increase in the supply of amino acids in the intestine. The highest concentrations of plasma urea were recorded from 2 to 4 hours after feeding. It was also during this period that the highest concentration of ammonia in the rumen fluid was recorded. And yet the urea concentration appears to be only slightly influenced by the ammonia concentration in the rumen fluid, for this tended to be higher on treatment $b$. Another source of urea is the ammonia released in the liver when gluconeogenesis from amino acids takes place. The most important of these amino acids are alanine and glutamic acid (Lindsay, 1982; Rémesy et al., 1986), while serine and aspartic acid have also been mentioned in this respect (Champredon et al., 1977; Rémesy et al., 1986). Glycine is only marginally glucogenic (Rémesy et al., 1986). The lower concentration of the glucogenic amino acids on treatment $B$ as compared with treatment $b$, together with the higher 
urea concentration, may be seen as an indication of gluconeogenesis (Champredon et al., 1977). Barej et al. (1981) introduced an index for gluconeogenesis: (Leu + Ile + Val): Ala. Motyl et al. (1984) noted an increase in this ratio in lactating cows under conditions of fast and hypoinsulinemia. The ratio in our experiment was significantly higher on treatment $B$, namely 2.06 vs 1.69 . A similar index with glutamic acid in the denominator was likewise significantly higher, namely 12.27 vs 9.57 .

It can be concluded that the gluconeogenesis from amino acids was not the result of the decomposition of tissue protein, since the glycine concentration was lower on treatment $\mathrm{B}$ than on $\mathrm{b}$. When tissue protein decomposes the glycine concentration in the blood rises (Champredon et al., 1977). On the other hand, trials have shown that whenever an increased supply of protein is recorded at the level of the intestine, the concentration of glycine in the blood decreases (Broderick et al., 1974; Bergen, 1979). In addition, the fact that the concentration of the branched amino acids was lower on treatment $B$ than on treatment $b$ leads to the conclusion that there was no extra decomposition of tissue protein.

Concentrations of methionine and phenylalanine were low on both treatments. Methionine is often mentioned as the first-limiting amino acid for milk protein production (Bergen, 1979; Rémond et al., 1971). When under the influence of slowly fermentable protein the supply of a limiting amino acid increases, this could lead to increased milk protein synthesis and a consequent decrease in the concentration of the other essential amino acids in the blood. Similarly, the decrease in the concentration of non-essential amino acids can be attributed not only to increased gluconeogenesis but also to increased milk protein formation. The lower insulin concentration on treatment $B$ is favourable to a preferential utilization by the udder of the extra amino acids absorbed from the intestine (Brockman \& Laarveld, 1986).

\section{Milk fat production}

The interpretation of the milk fatty acid pattern and the average daily excretion of milk fatty acids (Tables 7 and 8 ) is hampered by the presence of palm kernel fat in the concentrate with slowly degradable protein. The characteristic fatty acids of palm kernel fat, $C_{12: 0}$ and $C_{14: 0}$, are fatty acids which are also synthesized in the udder from lipogenic volatile fatty acids. The slightly higher secretion of the fatty acids with 6 to $10 \mathrm{C}$ atoms, however, points to an increased secretion of milk fat through a higher supply of acetate to the udder on treatment $B$, which is in accord with the higher acetate/propionate ratio in the rumen. The higher secretion of fatty acids originating wholy or partly from de novo synthesis in the udder exceeded the lower secretion of the $\mathrm{C}_{18}$ fatty acids.

\section{Conclusion}

The use of concentrates with slowly degradable protein results in more gradual rumen fermentation, which promotes a higher acetate/propionate ratio in the rumen fluid. This is favourable for milk fat synthesis. The somewhat lower concentration of propionic acid produces a lower concentration of insulin in the blood, which pro- 
motes the utilization of glucose and amino acids by the udder. Moreover, the lower fermentation of protein in the rumen leads to a higher supply of amino acids in the intestine, so that more protein as well as more lactose can be formed (Rulquin, 1983). The extra glucose production may lead to a saving of energy from adipose fat.

\section{References}

Barej, W., P. Ostaszewski \& M. Szczygiel, 1981. Could the plasma amino acid concentrations indicate on body protein turnover in sheep? Proceedings of the 6th International Symposium on Amino Acid Metabolism. Serock, Poland.

Bartle, S. J., R. L. Preston \& J. R. Males, 1983. Evaluation of plasma-free fatty acids as indicators of energy status in lactating beef cows. Nutrition Reports International $28: 345-354$.

Bergen, W. G., 1979. Free amino acids in blood of ruminants-physiological and nutritional regulation. Journal of Animal Science 49: 1577-1589.

Bickerstaffe, R., E. F. Annison \& J. L. Linzell, 1974. The metabolism of glucose, acetate, lipids and amino acids in lactating dairy cows. Journal of Agricultural Science (Cambridge) 82: 71-85.

Bines, J. A., 1968. Variation, in relation to feeding, in the levels of certain energy-yielding metabolites in the blood of a cow receiving an all-concentrate or all-hay diet. Proceedings of the Nutrition Society 27: 15A-17A.

Bines, J. A. \& I. C. Hart, 1984. The response of plasma insulin and other hormones to intraruminal infusion of VFA mixtures in cattle. Canadian Journal of Animal Science 64. Supplement: 304-305.

Blauwiekel, R. \& R. L. Kincaid, 1986. Effect of crude protein and solubility on performance and blood constituents of dairy cows. Journal of Dairy Science 69: 2091-2098.

Bowden, D. M. . 1971. Non-esterified fatty acids and ketone bodies in blood as indicators of nutritional status in ruminants: A review. Canadian Journal of Animal Science 51: 1-13.

Brockman, R. P. \& B. Laarveld, 1986. Hormonal regulation of metabolism in ruminants: a review. Livestock Production Science 14: 313-334.

Broderick, G. A., L. D. Satter \& A. E. Harper, 1974. Use of plasma amino acid concentration to identify limiting amino acids for milk production. Journal of Dairy Science 57: 1015-1023.

Champredon, C, B. Rémond \& R. Pion, 1977. Influence d'une sous-alimentation énergétique et azotée sur l'aminoacidémie libre de vaches laitières en début de lactation. Comptes rendus des séances de la Société de Biologie 171: 60-66.

Crooker, B. A., C. J. Sniffen, W. H. Hoover \& L. L. Johnson, 1978. Solvents for soluble nitrogen measurements in feedstuffs. Journal of Dairy Science $61: 437-447$.

Es, A. J. H. van, 1978. Feed evaluation for ruminants. I. The systems in use from May 1977 onwards in the Netherlands. Livestock Production Science 5: 311-345.

Evans, E., J. C. Buchanan-Smith \& G. K. MacLeod, 1975. Postprandial patterns of plasma glucose, insulin and volatile fatty acids in ruminants fed low- and high-roughage diets. Journal of Animal Science 41: 1474-1479.

Hart, I. C., J. A. Bines, S. V. Morant \& J. L. Ridley, 1978. Endocrine control of energy metabolism in the cow: comparison of the levels of hormones (prolactin, growth hormone, insulin and thyroxine) and metabolites in the plasma of high- and low-yielding cattle at various stages of lactation. Journal of Endocrinology 77: 333-345.

Johnson, D. D., G. E. Mitchell Jr., R. E. Tucker \& R. W. Hemken, 1982. Plasma glucose and insulin response to propionate in preruminating calves. Journal of Animal Science 55: 1224-1230.

Johnson, D. D., G. E. M. Mitchell, R. E. Tucker \& R. B. Muntifering, 1986. Pancreatic amylase, plasma glucose and insulin responses to propionate or monensin in sheep. Journal of Dairy Science 69: 5257.

Laarveld, B., D.A. Christensen \& R. P. Brockman, 1981. The effect of insulin on net metabolism of glucose and amino acids by the bovine mammary gland. Endocrinology 108: 2217-2221.

Lindsay, D. G., 1982. Relationships between amino acid catabolism and protein anabolism in the ruminant. Federation Proceedings 41: 2550-2554. 
Motyl, T., W. Barej \& W. Kukulska, 1984. Evaluation of muscle protein breakdown in lactating cows from urinary excretion of 3-methylhistidine and plasma amino acids levels. Zeitschrift für Tierphysiologie. Tierernährung und Futtermittelkunde 51: 51-57.

Muuse, B. G.. G. A. Werdmuller. J. P. Geerts \& R. J. de Knegt, 1986. Fatty acid profile of dutch butterfat. Netherlands Milk and Dairy Journal 40: 189-201.

Rémesy, C. Y. Chilliard. Y. Rayssiguier, A. Mazur \& C. Demigné, 1986. Le métabolisme hépatique des glucides et des lipides chez les ruminants: principales interactions durant la gestation et la lactation. Reproduction, Nutrition, Développement 26: 205-226.

Rémond, B., C. Champredon, C. Decaen, R. Pion \& M. Journet, 1971. Influence d'un apport de DLméthionine a des vaches au début de la lactation sur la production laitière et la composition du sang. Annales de Biologie animale Biochimie Biophysique 11: 455-469.

Roberts, C. J., I. M. Reid, S. M. Dew, A. J. Stark, G. D. Baird, R. Collins \& D. Mather, 1978. The effects of underfeeding for 6 months during pregnancy and lactation on blood constituents, milk yield and body weight of dairy cows. Journal of Agricultural Science (Cambridge) 90: 383-394.

Rulquin. H. . 1983. Effect sur la digestion et le métabolisme des vaches laitières d'infusions d'acides gras volatiles dans le rumen, et de caséinate dans le duodénum. II. Métabolisme général et mammaire. Reproduction, Nutrition, Développement 23: 1029-1042.

Snedecor, G. W. \& W. H. Cochran, 1968. Statistical Methods, 6th ed. Iowa State University Press, Ames, Iowa. USA.

Sutton, J. D. . I. C. Hart, W. H. Broster, R. J. Elliott \& E. Schuller, 1986. Feeding frequency for lactating dairy cows: effects on rumen fermentation and blood metabolites and hormones. British Journal of Nutrition 56: 181-192.

Veen, W. A. G.. 1986. The influence of slowly and rapidly degradable concentrate protein on a number of rumen parameters in dairy cattle. Netherlands Journal of Agricultural Science 34: 199-216.

Veen. W. A. G. \& Y. Tj. Bakker, 1988. The influence of slowly and rapidly degradable concentrate protein on a number of blood parameters in dairy cattle. Netherlands Journal of Agricultural Science, 36: 93-104.

Walstra, P. \& H. Mulder. 1962. Gravimetric methods for the determination of the fat content of milk and milk products. 2. The Röse-Gottlieb method. Netherlands Milk and Dairy Journal 16: 172-184.

Whitelaw, F. G., J. S. Milne, E. R. Ørskov \& J. S. Smith, 1986. The nitrogen and energy metabolism of lactating cows given abomasal infusions of casein. British Journal of Nutrition 55: 537-556. 